\title{
Risk Assessment of Pesticidal Toxicity and Threats on Pollinators: A Review on Honey Bee
}

\author{
Kushal Naharki ${ }^{1, a, *}$, Sabina Regmi ${ }^{2, b}$ \\ ${ }^{I}$ Institute of Agriculture and Animal Science, Lamjung Campus, Nepal \\ ${ }^{2}$ Institute of Agriculture and Animal Science, Paklihawa Campus, Nepal
}

*Corresponding author

\section{A R T I C L E I N F O A B S T R A C T}

Review Article

Pollinators play vital roles to the environment, biodiversity conservation, food security and several dimensions of global sustainable development. Honey bee is an important pollinator globally but has been exposed to increasing threats from diseases, pesticides and biotic stresses. This review paper highlights the role of honey bees as pollinators, addresses threats which influence decline of honey bees and assess pesticidal risk toxicity on non-target organisms. Decline of honey bee population is caused by several factors including habitat fragmentation, pesticidal toxicity, colony collapse disorder and climate change. Pesticidal residue and toxicity has an adverse effect which results in honey bee population decline, disturb foraging and contamination of bee products. Residues of agricultural pesticides like pyrethroid and neonicotinoid pose a serious threat on honey

Received : 08/06/2020 Accepted : 12/12/2020 bee health further reducing agricultural production and diversity. Pesticidal risk assessments are carried out to study effects of pesticides on pollinators with an aim to provide measures to safeguard their abundance, diversity and health. Sustainable agriculture, effective policy and proper management can decrease pollinators' risk by helping to diversify the agriculture for pollen and

Honey Bee Pesticidal Toxicity Pesticides Pollinators nectars with reduced usage of pesticides and proper management.

Threats

kushalnaharki@gmail.com (iD) https://orcid.org/0000-0003-3540-3216

b@sabinaregmi9@gmail.com

https://orcid.org/0000-0003-2149-7434

\section{Introduction}

Pollination is an essential ecosystem service for food production and maintenance of biological diversity (Gallai et al., 2008). Pollinators have succeeded many years, preserving biodiversity and environment ensuring food security and nutrition. They affect $75 \%$ of the leading food crop worldwide and $35 \%$ of the agricultural crop production (IPBES, 2016). There are 369,000 flowering plant species and $85 \%$ of plant species worldwide which are dependent on pollination (Kopec and Burd, 2017). Pollination is estimated to be worth 235 USD to 577 USD billion annually to global crop production (FAO, 2016).

Honey bee (Apis mellifera L.) is considered the most essential pollinator of agricultural crops and for bee products across the globe (Klein et al., 2007; CBD, 2018). One in every three bites of food people consume is made possible by bees (Cameron, 2018). Honey bee products have high economic importance with the increasing commercial value of honey with 1.6 million tons of honey and 65,000 ton of beeswax produced every year
(FAOSTAT, 2013). They have become a source of income, food security means and livelihood approach for many farmers and small-scale producers from developing nations (Silva, 2018).

Although demand for honey bees is increasing locally and regionally, we could be facing limitations of pollinators in the near future as growth in cultivation of high value, pollination-dependent crops are outpacing growth in the global stock of managed honey bees (Tirado et al., 2013). Colony losses have occurred in very high rates in Europe and North America particularly in past decades (Laurent et al., 2015; IPBES, 2016). Managed bee population decreased by $40.7 \%$ by one year in the United States from April 2018 to April 2019 (Neilson, 2019). The diminished honey bee colonies can lead to disastrous effects and have increased impacts on environmental diversity, food production, and economy (Potts et al., 2010). Several factors influence honey bee health including pests, diseases and pesticides. 
Pollinators have confronted a threat with the growing use of pesticides in agriculture with chemicals like, herbicides, fungicides and insecticides (Gallai et al., 2008). Pesticides create environmental and health risks with a common neonicotinoid pesticide, thiamethoxam posing threat to honey bees (Blacquiere et al., 2012). The base of pesticide risk assessment is to evaluate environmental and health impacts of the pesticidal compounds (US-EPA, 2014). The regulation for honey bee health states that components should have insignificant effects or no any acute or chronic impacts on survival, development and behavior of honey bees (EFSA, 2014).

It is essential to identify threats specific to bees with an essential baseline for risk assessments and conservation methods for a sustainable future. Enhancing pollinators density and diversity increases crop production. Crosscutting innovations with research and management on honey bees with knowledge in chemistry, molecular biology, pathology, genetics and extension is required with the understanding of the fundamentals of honey bee health (Moritz et al., 2010).

\section{Role of Honey Bee as Pollinator}

Bees are found in different types of climates from forests in Europe and Asia, deserts in Africa to Arctic Circle (Moisset and Buchmann, 2011). Common pollinating species include honey bees with moths, flies, wasps, beetles and butterflies. 25,000 to 30,000 species of bees are recorded with most of them being effective pollinators (FDA, 2018). Honey bee can visit between 501000 flowers in a single trip (Bradbear, 2009). Animals and humans are highly reliant on bees for their food security and ecosystem services as 3 out of 4 crops producing fruits or seeds are dependent on pollinators which are consumed by humans as food (UN, 2016). Honey bees are an indispensable part of the world's agricultural system and play critical roles in pollination, food and nutrition and share more than $90 \%$ of the pollination worldwide. In the last 50 years, agricultural production reliance on pollinators has enlarged by $300 \%$ (CBD, 2018).

\section{Threats to Pollinators}

Climate Change: Change in weather patterns with climate events like flood, droughts and increased global temperature can desynchronize the relation between honey bee and plants resulting disturbance in pollination activities and food for honey bee (Valk and Koomen, 2011). Slathia and Tripathi (2016) expected a sharp rise in rate of extinction with climate change. Bees are declining due to high heat in southern region whereas are becoming stationary in northern region as global temperatures rises. Bees are highly vulnerable to gut parasites and these parasites are increasing with warming weather conditions (Turner, 2019).

Colony Loss: Honey bee colony is called as "Super Organism" due to high interdependency of members and colony of bee survives only as a collective entity (Delaplane, 2016). Colony loss takes place due to several factors including diseases, pests, deprivation of nutrition and pesticidal residue (Hellerstein et al., 2017). Prevention of honey bee colony losses (COLOSS) reported $16.4 \%$ of honey bee colonies loss in 2017/18 winter with loss varying from 2.0 to $32.8 \%$ between countries (Gray et al., 2019).

Disease: Bees get sick when different factors suppress their immune systems and decrease their resistance. Bee pathogens might be fungal, viral and bacterial (Genersch, 2010). Nosema disease impairs bee's digestive system. Some of the most common diseases that can impact a colony are American Foulbrood, European Foulbrood, Chalkbrood, Sacbrood and Nosema (Genersch, 2010).

Food: Honey bee starvation can be a challenging problem with decrease in pollen and nectar. Numerous factors such as weather changes and extremes, availability of food reserves and presence of brood influences the rate at which food stored deplete. Over-harvesting of honey can also cause scarcity of food for bees (Leonard, 2011). Larval starvation declines and weakens bee colonies as bees become too weak to fly or unable to reproduce due to lack of food (Brodschneider, 2010).

Habitat Loss and Fragmentation: Beekeepers, mainly from United States and Europe, have reported annual hive losses of $30 \%$ or higher (Elizabeth, 2013). Habitats essential for honey bee are fragmented and degraded with change in land-use patterns, widening agricultural intensification and monoculture (Aizen et al., 2009).

Invasive Species: Invasive plant species capture the land, and other resources and outcompete natives for food and habitat. As native wildflowers that the bees feed on start to disappear due to invasive plant species it becomes harder for bees to find food. Wool-carder bees can act as an invasive species to bee colony (Grahman, 2015).

Parasites: Parasitic tracheal mites are a big problem for bees invading a bee's respiratory system. The Varroa mite is a serious pest and biotic stressor of honey bees which can cause Colony Collapse Disorder (CCD) as parasite and host for viruses (Boecking and Genersch, 2008). It transmits Acute bee paralysis virus (ABPV), Kashmir bee virus (KBV), Israeli acute paralysis virus (IAPV) and the Deformed Wing Virus (Ellis, 2016) acting as vector.

Pesticides: Pesticides are a major potential cause of honey bee decline. Pesticide residues include acaricides, organic acids, insecticides, fungicides, herbicides and bactericides (Zhu et al., 2014). Many of the pesticides are lipophilic compounds like pyrethroids, organophosphates, fungicides and herbicides (Faucon et al., 2002). The agrochemicals like neonicotinoid and neurotoxic insecticides can degrade bee health with their occurrence in pollen and nectar collected by honey bee (Simon-Delso et al., 2016).

\section{Pesticidal Use}

\section{Agriculture Pesticide}

Cropping and pesticide application practices, pesticides properties, and attractiveness to honey bees influence the probability and degree of exposure to pesticides. The overlap of pesticide applications with crop flowering or with the activity in the crop area acts as the major factor influencing risk. In foliar applications during agricultural practices, the pesticide is sprayed on the plant surface to kill targeted insect pests (Ferrier et al., 2018).

Chlorpyrifos is a globally used organophosphate in agriculture management with its residues often found in honey, propolis and dead bees (Donovan, 2006). 
Neonicotinoids are environmentally persistent pesticides heavily used in agriculture to save crops (Tomizawa and Casida, 2005) and they are spotted in guttation droplets, nectar and pollen accumulated by honey bee (Bonmatin et al., 2015). The exposure to even low concentrations of neonicotinoids shows sublethal behavioral effects and impacts bee health via systemic interactions (Godfray et al., 2015).

\section{Apiculture Pesticide}

High demand for honey bee services, increasing pest and disease problems have kept beekeepers reliant on pesticides used in apiculture. Miticides such as organophosphate and pyrethroid along with several treatments for control of infestations in hive are commonly used chemicals on honey bees with major potential influences on bee farming (Kakumanu et al., 2016). Mullin et al. (2010) recorded 121 pesticides and metabolites in bee hive with an average of 7 pesticides per pollen sample which consisted of miticides, insecticides, fungicides, herbicides, and insect growth regulators.

Heavy metals, bacteria, radio-active materials and pesticides leads to pollution of bee products including honey, wax and other products. The direct exposure of pesticides in bee hives results to significant contamination of honey along with other hive products.

Pyrethroid tau-fluvalinate and the organophosphate coumaphos are broadly used to control Varroa mite which have high persistence in bee wax with 5 year half-life (Zhu et al., 2014).

\section{Routes of Pesticidal Toxicity}

Exposure of bees can be classified based on application procedures and the persistence of pesticides in nature. Cresswell (2016) describes the channel of pesticides exposure to honey bees and other pollinators as:

- Contact with pesticidal residues on sprayed objects

- Direct exposure of pesticides to beehive

- Exposure with pesticides and ingestion of residues while foraging

- Pesticidal runoff from Guttation fluid and puddles

- Pollen pesticidal residue through seed treatment

\section{Pesticidal Toxicity}

\section{Pesticidal Risk Assessments}

Pesticidal risk assessments are carried out to study effects of pesticides on non-target organisms and the method includes evaluation of toxicity and exposure levels of pesticides (Thompson, 2010). Pollinator health risk and pesticide exposure differ across different conditions. Lethal Dose $\left(\mathrm{LD}_{50}\right)$ or Lethal Concentration $\left(\mathrm{LC}_{50}\right)$ are used for the assessment of the pesticidal risks. It measures the toxicity and effects of the pesticides with exposure thresholds. Pesticide risk assessments require path of pesticide subjection, pesticidal concentrations and toxicity (acute, chronic, and sublethal) followed by assessing the correlation of exposure and lethality (Muth et al., 2003; Burgett et al., 2010). Cresswell (2016) found that pesticidal risks are extremely reliant on the amount and dosage of pesticides studying the risk posed by pyrethroids and neonicotinoids on exposure to honey bee (Table 1).
Table 1. Pesticides toxicity to bees by contact or oral exposure and their persistence in soil (half-life)

\begin{tabular}{|c|c|c|c|}
\hline Chemical name & $\begin{array}{c}\text { Contact }^{1} \\
\text { LD50 } \\
(\mu \mathrm{g} / \text { bee })\end{array}$ & $\begin{array}{c}\text { Oral }^{1} \\
\text { LD50 } \\
(\mu \mathrm{g} / \mathrm{bee})\end{array}$ & $\begin{array}{l}\text { Half- } \\
\text { life }^{2} \\
\text { (days) }\end{array}$ \\
\hline \multicolumn{4}{|c|}{ Acaricides } \\
\hline Acrinathrin & 0.17 & 0.12 & 22 \\
\hline Amitraz & 50 & - & 1 \\
\hline Coumaphos & 20 & 4.6 & - \\
\hline Fenpyroximate & 11 & - & 49 \\
\hline Tau-fluvalinate & 8.7 & 45 & 4 \\
\hline Tetradifon & 1250 & - & 112 \\
\hline \multicolumn{4}{|c|}{ Fungicides } \\
\hline Azoxystrobin & 200 & 25 & 78 \\
\hline Boscalid & 200 & 166 & 118 \\
\hline Captan & 215 & 91 & 4 \\
\hline Carbendazim & 50 & - & 22 \\
\hline Chlorothalonil & 135 & 63 & 44 \\
\hline Myclobutanil & 40 & 34 & 35 \\
\hline Propiconazole & 50 & 77 & 214 \\
\hline Quintozene & 71 & - & 210 \\
\hline Tebuconazole & 200 & 83 & 47 \\
\hline \multicolumn{4}{|c|}{ Herbicides } \\
\hline Metolachlor & - & 110 & 90 \\
\hline Norflurazon & 1485 & - & 225 \\
\hline Simazine & 879 & - & 90 \\
\hline \multicolumn{4}{|c|}{ Insecticides } \\
\hline Beta-cyfluthrin & 0.031 & 0.050 & 13 \\
\hline Bifenthrin & 0.015 & 0.20 & 87 \\
\hline Carbofuran & 0.16 & - & 14 \\
\hline Chlorpyrifos & 0.072 & 0.24 & 50 \\
\hline Clothianidin & 0.039 & 0.004 & 121 \\
\hline Cypermethrin & 0.034 & 0.064 & 69 \\
\hline DDT & 8.8 & 5.1 & 6200 \\
\hline Diazinon & 0.38 & 0.21 & 18 \\
\hline Endosulfan & 6.4 & 21 & 86 \\
\hline Fenthion & 0.22 & - & 22 \\
\hline Fipronil & 0.007 & 0.001 & 142 \\
\hline Imidacloprid & 0.061 & 0.013 & 174 \\
\hline Malathion & 0.47 & 9.2 & 1 \\
\hline Mevinphos & 0.094 & - & 1 \\
\hline Pyrethrum & 0.18 & 0.057 & - \\
\hline
\end{tabular}

\section{Pesticidal Threats}

Decreased division of labour: $31.6 \%$ of exposed honey bees fails to go back to their hive every day (Henry et al., 2012) while other can bring the contamination to the hive. Contaminated pollen brought by worker bees will not only affect the worker bees but also the queen. The regular laying rate of queen will decline when contaminated pollen or pesticides are brought back to the hive.

Honey bee health: The proficiency of honey bees is due to their colony formation, physique and their foraging consistency (Kumar et al., 2020). Acute toxicity to sublethal and chronic effects can be seen on honey bee health. The collection of nectar and pollen with pesticide residues affects honey bee health to a greater extent. It is found that acute or chronic contact to a neonicotinoid (Erik, 2012) alone can significantly alter flight in honey bees and damages normal activities of honey bee like foraging (Henry et al., 2012; Tosi et al., 2017). 
Substantial alteration in structure and functional potential of gut bacteria in honey bee was resulted due to the impact of chlorothalonil (Kakumanu et al., 2016). Sublethal doses of pesticides impact many activities in bee like learning, orientation, foraging, feeding and immunocompetence (Cresswell, 2016). Several neural consequences are seen along with agonists of insect nicotinic acetylcholine receptor (nAChR) due to Neonicotinoids and its degradation products (Belzunces et al., 2012).

Honey and other bee products: Honey bee produces essential products like honey, wax, propolis and royal jelly. Bee products are polluted from the environmental contaminations and management during beekeeping. About three quarters of all honey worldwide is contaminated with pesticides (Potenza, 2017). Beeswax is polluted with the long-term use of the miticides fluvalinate, coumaphos, amitraz (Mullin et al., 2010). Antibiotic residues have a comparatively long half-life and therefore the widespread use of antibiotics results in accretion of antibiotic residues in honey and eventually resulting to diminished quality of bee products (Tillotson et al., 2006).

Increased mortality: Continuous exposure of honey bee to fungicides, pesticidal contamination and toxins effects honey bee populations in colonies (Zhu et al., 2014). Introduction of pesticides also increases vulnerability of diseases which rises the mortality rate in honey bee. Insects might face the decline of $40 \%$ of invertebrate pollinator species with loss in butterflies and bees in particular. With decline of $87 \%$ of population in rusty-patched bumble bee, it was registered as endangered species in 2017 (Ertiz, 2017).

Negative effects on brood development: Survival and development of honey bee will be affected with the continuous exposure to pesticides with inadequate nutrition and direct poisoning in honey bees. Brood production is heavily influenced by scarcity and deficiency of nutrients as larvae are dependent on protein especially with effects on fecundity, survival, growth and development (Dai et al., 2010).

Reduced fitness of treated colony: Honey bee activates its navigation memory during orientation flights and foraging. It is found that thiamethoxam decreases the return rate in honey bee affecting the foraging capacity in honey bee (Henry et al., 2012). Neonicotinoids like clothianidin, imidacloprid and thiacloprid can harm navigation even at sublethal doses. They either block the recall of remote navigation memory or modify it (Fischer et al., 2014). Reduced hive cleaning and self-grooming have been associated with insecticide - induced alteration of immune system pathways in honey bee (Pettis et al., 2012).

\section{Protection Measures}

Protection of pollinators can enhance global food security to maintain zero hunger to feed the growing world population and reduce poverty ensuring increase in agricultural production. Safeguarding bees also safeguards biodiversity. Crop production can be increased by $25 \%$ with proper management of pollination and pollinators (Silva, 2018). Honey bee require adequate nutrition in a balanced way for their survival and development (Huang,
2010) and larvae number may be lowered to nourish the remaining colonies with enough nutrition (Brodschneider, 2010). Varroa mites control is essential to control the spread of viruses in bee colonies but Varroacides must be minimally harmful to the bees, while maintaining toxicity to mites.

Ellis (2016) suggests curative and preventive health measures to protect bee colonies form the biotic stressors. Farmers can protect honey bee health, pollinator abundance and diversity by integrating their experience, skills and indigenous knowledge with scientific learnings to create innovative methods. They should be encouraged to practice pollinators friendly agricultural management. Government agencies, non-government organizations, extension agencies, academic bodies should work in cooperation with farmers to conduct researches, monitor and evaluate pollinator status and maintain their population and health (Barriere et al., 2019).

\section{Conclusion}

Helping honey bees is essential to our continued survival, health, and well-being. Abundance, diversity and health of bees should be ensured to safeguard pollinators from threats. Public land managers and private landowners, including farmers should be encouraged to adopt pollinator friendly practices. Proper risk assessment to honey bee information is needed on toxicity of the pesticide, probability of the bee exposure to the pesticide and the natural history and population of population dynamics. It is necessary to increase awareness in all aspects of pollination and pollinators and in the major threats and pesticidal toxicity. Policies that favor pollinators, promote biological pest control as well as limit the use of pesticides should be implemented with strengthening the participation of local communities in decision-making.

\section{References}

Aizen M A, Lucas G A, Cunningham S A, Klein A. 2009. How much does agriculture depend on pollinators? Lessons from long-term trends in crop production. Annals of botany, 103(9): 1579-1588. doi:10.1093/aob/mcp076

Barriere O, Behnassi M, Gilbert D, Douzal V, Fargette M, Libourel T. 2019. Coviability of Social and Ecological Systems: Recommending Mankind to the Biosphere in an Era of Global Change. Springer. doi:10.1007/978-3-319-78497-7

Belzunces L, Tchamitchian S, Brunet, J. 2012. Neural effects of insecticides in the honey bee. Apidologie, 43: 348-370. doi:10.1007/s13592-012-0134-0

Blacquiere T, Smagghe G, Gestel, KV, Mommaerts V. 2012. Neonicotinoids and bees: an overview on concentrations, side effects and risk assessment. Ecotoxicology, 20: 973-992.

Boecking O, Genersch E. 2008. Varroosis- the ongoing crisis in bee keeping. Journal of Consumer Protection and Food Safety, 3: 221-228.

Bonmatin J, Giorio C, Girolami V, Goulson D, Kreutzweiser D, Krupke C, Liess M, Long E, Marzaro M, Mitchell E, Noome D, Simon-Delso N, Tapparo A. 2015. Environmental fate and exposure; neonicotinoids and fipronil. Environmental Science and Pollution Research, 35-67. doi:10.1007/s11356014-3332-7

Bradbear N. 2009. BEES AND THEIR ROLE IN FOREST LIVELIHOODS. FAO. Viale delle Terme di Caracalla, 00153 Rome, Italy. ISBN 978-92-5-106181-7(Online) 
Brodschneider R. 2010. Nutrition and health in honey bees. Apidologie, 41: 278-294. doi: 10.1051/apido/2010012

Burgett M, Daberkow S, Rucker R. 2010. U.S. POllination Markets: Recent Chnages and Historical Perspective. American Bee Journal. 150(1): 35-41.

Cameron, L. 2018. Michigan State University. BEYOND HONEY BEES. Available from: https://msutoday.msu.edu/news/ 2018/beyond-honey-bees/ [Accessed May 15 2020]

CBD. 2018. Global Survey of Honeybees And Other Pollinators. Convention on Biodiversity. Montreal, Canada.

Cresswell J. 2016. The Impacts of Agrochemical Pesticides on Bees in Intensively Cultivated Farmland. Pollination Services to Agriculture. doi: 10.4324/9781315696355

Dai P, Wang Q, Sun J, Liu F, Wang X, Wu Y, Zhou T. 2010. Effects of sublethal concentrations of bifenthrin and deltamethrin on fecundity, growth, and development of the honeybee Apis mellifera ligustica. Environmental Toxicology and Chemistry 29(3), 644-9. doi: 10.1002/etc.67

Delaplane K. 2016. Tissues and Organs in the Superorganism. American Bee Journal, 156(7), 785-788.

Donovan Y. 2006. Reregistration Eligibility Decision for Chlorpyrifos. U.S.Environmental Protection Agency, Office of Pesticide Programs.

EFSA. 2014. Towards an integrated environmental risk assessment of multiple stressors. EFSA Journal, 12(3). doi:10.2903/j.efsa.2014.3594

Elizabeth G. 2013. YaleEnvironment360. Declining Bee Population Pose a Threat to Global Agriculture. Available from: https://e360.yale.edu/features/declining_bee_populations _pose_a_threat_to_global_agriculture [Accessed 5 May 2020]

Ellis J. 2016. Biotic Stressors of Honey Bee Colonies. American Bee Journal, 156(7): 377.

Erik S. 2012. Field Research on Bees Raises Concern About LowDose Pesticides. Science, 335. doi: 10.1126/science. 335.6076.1555

Ertiz O. 2017. NBC News. Rusty Patched Bumble Bee is Put on Endangered Species list After Trump Administration Delay. Available from: https://www.nbcnews.com/news/us-news/ rusty-patched-bumble-bee-put-endangered-species-list-aftertrump-n736536 [Accessed 19 April 2020]

FAO. 2016. Food And Agriculture Organization. Pollinators vital to our food supply under threat. Available from: http://www.fao.org/news/story/en/item/384726/icode/ [Accessed 17 March 2020]

FAOSTAT. 2013. Food And Agriculture Organization. Dataset 2013. Available from: http://faostat.fao.org/ [Accessed 8 April 2020]

Faucon J, Mathieu L, Ribiere M, Martel A, Drajnudel P, Zeggane S, Aubert M. 2002. Honey bee winter mortality in France in 1999 and 2000. Bee World, 83(1): 14-23. doi:10.1080/ 0005772X.2002.11099532

FDA. 2018. Food and Drug Administration. Helping Agriculture's Helpful Honey Bees. Available from: https://www.fda.gov/animal-veterinary/animal-healthliteracy/helping-agricultures-helpful-honey-bees [Accessed 29 March 2020]

Ferrier P, Rucker R, Thurman W, Burgett M. 2018. Economic Effects and Responses to Changes in Honey Bee Health. ERR-246, U.S. Department of Agriculture, Economic Research Service.

Fischer J, Müller T, Spatz A, Greggers U, Grünewald B, Menzel R. 2014. Neonicotinoids Interfere with Specific Components of Navigation in Honeybees. PLoS ONE, 9(3).

Gallai N, Salles J, Settele J, Vaissiere B. 2008. Economic valuation of the vulnerability of world agriculture confronted with pollinator decline. ECOLOGICAL ECONOMICS, 6: 810-821. doi:10.1016/j.ecolecon.2008.06.014

Genersch E. 2010. Honey bee pathology: current threats to honey bees and bee keeping. Microbial Biotechnol, 67: 87-97. doi:1007/s00253-010-2573-8
Godfray H, Blacquière T, Field LM, Hails R, Potts S, Raine NE, McLean A. 2015. A restatement of recent advances in the natural science evidence base concerning neonicotinoid insecticides and insect pollinators. The Royal Society. doi:10.1098/rspb.2015.1821

Grahman K. 2015. The Conversation. Bee battles: why our native pollinators are losing the war. Available from: https://theconversation.com/bee-battles-why-our-nativepollinators-are-losing-the-war-40620 [Accessed 11 March 2020]

Gray A, Brodschneider R, Adjlane N, Ballis A, Brusbardis V, Charrière J, Chlebo R, Coffey M, Cornelissen B, Costa C, Csáki T, Dahle B, Danihlík J, Dražić M, Evans G, Fedoriak M, Forsythe I, Graaf D, Gregorc A, Johannesen J, Kauko L, Kristiansen P, Martikkala M, Martín-Hernández R, MedinaFlores C, Mutinelli F, Patalano S, Petrov P, Raudmets A, Ryzhikov V, Simon-Delso N, Stevanovic J, Topolska G, Uzunov A, Vejsnaes F, Williams A, Zammit-Mangion M, SorokeGray V. 2019. Loss rates of honey bee colonies during winter 2017/18 in 36 countries participating in the COLOSS survey, including effects of forage sources. Journal of Apicultural Research, 58(4). doi:10.1080/00218839. 2019.1615661

Hellerstein D, Hitah C, Smith D, Davis A. 2017. Land Use, Land Cover, and Pollinator Health: A review and Trend Analysis. Economic Research Report No. 323, U.S. Department of Agriculture, Economic Research Service. pp. 47.

Henry M, Beguin M, Requier F, Rollin O, Odoux J, Aupinel P, Aptel J, Tchamitchian S, Decourtye A. 2012. A Common Pesticide Decreases Foraging Success and Survival in Honey Bees. Science, 336: 348-350. doi:10.1126/science.1215039

Henry M, Cerrutti N, Aupinel P, Decourtye A, Gayrard M, Odoux J, Pissard A, Rüger C, Bretagnolle V. 2015. Reconciling laboratory and field assessments of neonicotinoid toxicity to honeybees. The Royal Society, 282. doi:10.1098/rspb. 2015.2110

Huang Z. 2010. Bee Health. Honey Bee Nutrition. Available from: https://bee-health.extension.org/honey-bee-nutrition/. [Accessed 4 May 2020]

IPBES. 2016. Summary for policymakers of the assessment report of the Intergovernmental Science-Policy Platform on Biodiversity and Ecosystem Services on pollinators, pollination and food production. Secretariat of the Intergovernmental Science- Policy Platform on Biodiversity and Ecosystem Services, Bonn, Germany. pp. 36.

Kakumanu M, Reeves A, Anderson T, Rodrigues R, Williams M. 2016. Honey Bee Gut. Frontiers in Microbiology Microbiome Is Altered by In-Hive Pesticide Exposures. doi: 10.3389/fmicb.2016.01255

Klein A, Vaissière B, Cane J, Steffan-Dewenter I, Cunningham S, Kremen C, Tscharntke T. 2007. Importance of pollinators in changing landscapes for world crops. Proceedings of the Royal Society, 274: 311-323. doi: 10.1098/rspb.2006.3721

Kopec K, Burd L. 2017. Pollinators in Peril: A systematic status of North American and Hawaiian native bee. Center for Biological Diversity.

Kumar G, Singh S, Nagarajaiah RP. 2020. Detailed Review on Pesticidal Toxicity to Honey Bees and Its Management. In Modern Beekeeping - Bases for Sustainable Production. IntechOpen. doi:10.5772/intechopen.91196

Laurent M, Hendrikx P, Ribiere-Chabert M, Chauzat M. 2015. European Commission. A pan-European epidemiological study on honeybee colony losses 2012-2014. Available from: https://ec.europa.eu/food/sites/food/files/animals/docs/la_be es_epilobee-report_2012-2014.pdf [Accessed 17 April 2020]

Leonard E. 2011. GARDENFORK. WHAT HONEYBEE STARVATION LOOKS LIKE IN A BEEHIVE. Available from: https://www.gardenfork.tv/what-honeybee-starvationlooks-like-in-a-beehive/ [Accessed 22 April 2020] 
Moisset B, Buchmann S. 2011. Bee Basics: An Introduction to our Native Bees. USDA Forest Service and Pollinator Partnership. Washington, DC.

Moritz R, Miranda J, Fries I, Conte Y, Neumann P, Paxton R. 2010. Research strategies to improve honeybee health in Europe. Apidologie, 41: 227-242. doi: 10.1051/apido/ 2010010

Mullin C, Frazier M, Frazier J, Ashcraft S, Simonds R, vanEngelsdorp D, Pettis J. 2010. High Levels of Miticides and Agrochemicals in North American Apiaries: Implications for Honey Bee Health. PLosOne, 5(3). doi:10.1371/ journal.pone.0009754

Mussen E. 2011. Bee Brief: Diagnosing and Treating Nosema Disease. University og California, Davis.

Muth M, Thurman W, Chuang C. 2003. The Fable of the Bees Revisited: Causes and Consequences of the U.S. Honey Program. JOURNAL OF Law and Economics, 46(2): 479516.

Neilson S. 2019. The Salt. Retrieved from More Bad Buzz For Bees: Record Number Of Honeybee Colonies Died Last Winter. Available From: https://www.npr.org/sections/ thesalt/2019/06/19/733761393/more-bad-buzz-for-beesrecord-numbers-of-honey-bee-colonies-died-last-winter [Accessed 05 May 2020]

Notter D. 1999. The importance of genetic diversity in livestock populations of the future. Journal of Animal Science, 77: 61-69.

Pettis J, vanEngelsdorp D, Johnson J, Dively G. 2012. Pesticide exposure in honey bees results in increased levels of the gut pathogen Nosema. Naturwisenschaften, 99: 153-158.

Pisa L, Amaral-Rogers V, Belzunces L, Bonmatin J, Downs C, Goulson D, Kreutzweiser D, Krupke C, Liess M, McField M, Morrissey C, Noome D, Settele J, Simon-Delso N, Stark J, Van der Sluijs J, Van Dyck H, Wiemers M. 2015. Effects of neonicotinoids and fipronil on non-target invertebrates. Environmental Science and Pollution Research, 22: 68-102. doi:10.1007/s11356-014-3471-x

Potenza A. 2017. The Verge. Bad news for bees: three-quarters of all honey on Earth has pesticides in it. Available from: https://www.theverge.com/2017/10/5/16424216/honeyneonicotinoids-contamination-honeybees-pollinatorsenvironment [Accessed 05 May 2020]

Potts S, Biesmeijer J, Kremen C, Neumann P, Schweiger O, Kunin W. 2010. Global pollinator declines: trends, impacts and driver. Trenda in Ecology and Evolution, 25(6): 345-353. doi: 10.1016/j.tree.2010.01.007

Sanchez-Bayo F, Goka K. 2014. Pesticide Residues and Bees - A Risk Assessment. PLOSONE. doi:10.1371/journal.pone. 0094482

Silva D. 2018. Food and Agriculture Organization. The importance of bees and other pollinators for food and agriculturel. Available from: http://www.fao.org/3/i9527en/ i9527en.pdf [Accessed 11 April 2020]
Simon-Delso N, Amaral-Rogers V, Belzunces L. 2016. Systemic insecticides (neonicotinoids and fipronil): trends, uses, mode of action and metabolites. Environmental Science and Pollution Research, 34(5). doi:10.1007/s11356-014-3470-y

Slathia I, Tripathi N. 2016. Impact of Climate Change on HoneyBee Populations and Diseases. Bio Bulletin, 2(1): 40-42.

Thompson H. 2010. Risk Assessment for Honey Bees and Pesticides--Recent Developments and 'New Issues'. Pest Manag Sci, 66(11). doi:10.1002/ps.1994

Tillotson G, Doern G, Blondeau J. 2006. Optimal antimicrobial therapy: the balance of potency and exposure. Expert Opinion on Investigational Drugs, 15(4): 335-337.

Tirado R, Simon G, Johnston P. 2013. Bees in Decline. Amsterdam, The Netherlands: Greenpeace International.

Tomizawa M, Casida, J. 2005. Neonicotinoid Insecticide Toxicology: Mechanisms of Selective Action. Annual Review of Pharmacology and Toxicology, 45: 247-268. doi:10.1146/annurev.pharmtox.45.120403.095930

Tosi S, Burgio G, Nieh J. 2017. A common neonicotinoid pesticide, thiamethoxam, impairs honey bee flight ability. Scientific Reports. doi:n10.1038/s41598-017-01361-8

Turner S. 2019. Acclimatise News. Impact of Climate Change On Bees And Food Production. Available from: http://www.acclimatise.uk.com/2019/08/26/impact-ofclimate-change-on-bees-and-food-production/ [Accessed 20 March 2020]

UN. 2016. United Nations. Countries urged to prioritize protection of pollinators to ensure food security at UN Biodiversity Conference. Available from: https://www.un.org/ sustainabledevelopment/blog/2016/12/pollinators/ [Accessed 1 March 2020]

US-EPA. 2014. United States Environmental Protection Agency. Guidance for Assessing Pesticide Risks to Bees. Available from: https://www.epa.gov/sites/production/files/2014-06/documents/ pollinator_risk_assessment_guidance_06_19_14.pdf [Accessed 12 May 2020]

Valk H, Koomen I. 2011. Food and Agriculture Organization. Aspects Determining The Risk of Pesticides to Wild Bee: Risk Profiles for Focal Crops on Three Continents. Available from: http://www.fao.org/3/a-i3116e.pdf [Accessed 25 May 2020]

Winston M. 2014. New York Times. Our Bees, Ourselves. Available from: https://www.nytimes.com/2014/07/15/opinion/ bees-andcolony-collapse.html?referrer\&_r=0 [Accessed 11 April 2020]

Zhu W, Schmehl D, Mullin C, Frazier J. 2014. Four Common Pesticides, Their Mixtures and a Formulation Solvent in the Hive Environment Have High Oral Toxicity to Honey Bee Larvae. PlosOne. doi:10.1371/journal.pone.0077547 